\title{
Evaluation of Survival Using American Society of Anesthesiology and Modified Charlson Comorbidty Index Scores in Geriatric Patients Undergoing Thoracic Surgery
}

Fatih Doğu Geyik ๑ Yücel Yüce $\odot$

Banu Çevik $\odot$

Kemal Saraçoğlu ๑

\section{Torasik Cerrahi Geçiren Geriyatrik Hastalarda Amerikan Anestezistler Derneği ve Modifiye Charlson Komorbidite Skorlarının Sağkalım Değerlendirmesi}

Etik Kurul Onayı: Kartal Dr. Lütfi Kırdar Eğitim ve Araştırma Hastanesi Klinik Araștırmalar Etik Kurul onayı alındı (26.12.2018/514/144/1)

Çıkar Çatışması: Çalışmaya ait herhangi bir çıkar çatışması bulunmamaktadır. Finansal Destek: Çalışma ile ilgili herhangi bir finansal destek bulunmamaktadır. Hasta Onamı: Tüm hastalardan çalışma için yazılı onam alındı.
Ethics Committee Approval: Kartal Dr. Lütfi Kurdar Training and Research Hospital Clinical Research Ethics Committee approval was obtained (26.12.2018/514/144/1). Conflict of Interest: There is no conflict of interest regarding the study. Funding: There is no funding for this study.

Informed Consent: Written consent was obtained from all patients for the study.

Cite as: Geyik FD, Yüce Y, Cevik B, Saraçoğlu K. Evaluation of survival using American Society of Anesthesiology and Modified Charlson Comorbidty Index scores in geriatric patients undergoing thoracic surgerycic surgery. GKDA Derg. 2021;27(2):131-8.

ABSTRACT

Objective: We aimed to evaluate the relationship between preoperative American Society of Anesthesiology and Modified Charlson Comorbidty Index scores and postoperative survival in geriatric patients who had undergone thoracic surgery.

Methods: A total of 109 patients aged 65 years and above who had undergone thoracic surgery under elective conditions were included in this retrospective study.

Results: Patients who died within the first postoperative two years had higher American Society of Anesthesiology III-IV scores $(p=0.03)$, higher Modified Charlson Comorbidty Index scores $(p=0.04)$, and lower hemoglobin and hematocrit values $(p=0.02$ and $p=0.005$, respectively). We found that Modified Charlson Comorbidty Index was significantly effective in predicting two-year mortality among geriatric patients $(A \cup C=0.648,95 \%$ Cl: 0.516-0.780, $p=0.02)$. In the ROC analysis, the best predictive cut-off value for Modified Charlson Comorbidty Index was found to be 7 (sensitivity: $79.7 \%$, and specificity: $44.4 \%$ ).

Conclusion: The cautious choice of patients for the medical procedure has contributed to the improvement in mortality rates after some time, and with refinements in preoperative testing meticulous patient selection should be maintained.

Keywords: elderly, thoracic surgery, mortality

ÖZ

Amaç: Torasik cerrahi geçirmiş geriyatrik hastaların preoperatif American Society of Anesthesiology ve Modified Charlson Comorbidty Index skorları ile postoperatif sağkalım arasındaki ilişkiyi değerlendirmeyi amaçladık.

Yöntem: Bu retrospektif çalışmaya elektif koşullarda göğüs cerrahisi geçirmiş 65 yaş ve üzeri 109 hasta dahil edildi.

Bulgular: Illk iki yıl içinde ölen hastaların daha yüksek American Society of Anesthesiology III-IV skorları ( $p=0.03)$, daha yüksek Modified Charlson Comorbidty Index skorları $(p=0.04)$ ve daha düşük hemoglobin ve hematokrit değerleri (sırasıyla $p=0.02$ ve $p=0.005$ ) vardı. Geriyatrik hastalar arasında Modified Charlson Comorbidty Index skorlarının iki yıllık mortaliteyi öngörmede anlamlı derecede etkili olduğunu bulduk (AUC=0.648,\% 95 Cl: 0.516-0.780, p=0.02). ROC analizinde, Modified Charlson Comorbidty Index için en iyi kestirim değeri 7 olarak bulundu (duyarlılık:\%79.7, özgüllük:\%44.4).

Tartışma: Cerrahi prosedür için hastaların dikkatli seçimi, ileride mortalitede iyileşmeye katkıda bulunabilir. Preoperatif testlerdeki iyileştirmeler ile ayrıntılı hasta seçimi yapılmaya devam edilmelidir.

Anahtar kelimeler: yaşlı hasta, göğüs cerrahisi, ölüm hızı
Received/Geliș: 05.02.2021

Accepted/Kabul: 17.03.2021

Published Online/Online yayın: 03.06.2021

Fatih Doğu Geyik Sağlık Bilimleri Üniveritesi Dr. Lütfi Kırdar Kartal Eğitim ve Araştırma Hastanesi, Ameliyathane İstanbul, Türkiye dogugeyik@hotmail.com ORCiD: 0000-0003-3626-238X

Y. Yüce 0000-0003-0396-1248

B. Çevik 0000-0002-7872-1794 K. Saraçoğlu 0000-0001-9470-7418 Sağlık Bilimleri Üniveritesi

Dr. Lütfi Kırdar Kartal Eğitim ve Araştırma Hastanesi, Ameliyathane istanbul, Türkiye

(C) Telif hakkı Göğüs Kalp Damar Anestezi ve Yoğun Bakım Derneği'ne aittir. Logos Tıp Yayıncılık tarafindan yayınlanmaktadır. Bu dergide yayınlanan bütün makaleler Creative Commons Attf-Gayri Ticari 4.0 Uluslararası Lisansı ile lisanslanmıştr.

(c) Copyright The Society of Thoracic Cardio-Vascular Anaesthesia and Intensive Care. This journal published by Logos Medical Publishing. Licenced by Creative Commons Attribution-NonCommercial 4.0 International (CC BY) 


\section{INTRODUCTION}

Surgery of the lungs and other intrathoracic structures and anesthesia applications are complicated procedures in both developed and developing countries ${ }^{[1]}$. Perioperative follow up of geriatric patients who underwent thoracic surgery is common among surgeons, anesthesiologists, and chest and intensive care physicians. Anesthesia for intrathoracic surgery in geriatric patients should maintain physiological stability, reduce surgical trauma to the lungs, and provide postoperative analgesia ${ }^{[2]}$.

The American Society of Anesthesiologists (ASA) classification is an evaluation system that classifies operation risk preoperatively and is considered useful for determining the appropriate anesthetic approach, especially the monitoring methods. Indices such as the Charlson comorbidity index $(\mathrm{CCl})$ and the Charlson age corrected comorbidity index ( $\mathrm{CACl}$ ) are used to determine comorbidity in surgical or internal problems ${ }^{[3]}$.

In intrathoracic procedures, there are problems related to the position, thoracotomy, and existing pathology in addition to the risks of a major operation. The factors that characterize thoracic anesthesia are the general condition of the patient, associated anomalies, protection of the healthy lung from secretion and blood, and lung collapse. One-lung ventilation (OLV) is the oxygenation of the blood and the elimination of $\mathrm{CO}_{2}$ from the blood by venting only one lung. OLV is the most important anesthetic application during thoracic surgery ${ }^{[4]}$. While perfusion continues in the collapsed lung during OLV, lack of ventilation causes right-to-left intrapulmonary shunt. With the mixing of nonoxygenated blood from the collapsed lung with oxygenated blood from the ventilated dependent lung, the alveolar-arterial oxygen gradient increases, and hypoxemia may develop ${ }^{[5]}$.

In recent years, there has been an increase in the geriatric patient population in parallel with the preventive and therapeutic developments in the field of health. With this change in population and the advancements in the use of anesthesia, surgery has become applicable to a more diverse disease type and an increasing number of patient populations ${ }^{[6]}$. It is predicted that approximately half of the population over 65 years of age in Western countries will require surgical intervention during their lifetime ${ }^{[7]}$.

The Goldman criteria are used to determine the elevated risk for elective surgery. Today, some studies have reflected that the 90-day mortality is much higher than the 30-day mortality ${ }^{[8]}$. Functional status, physiologic age (not chronologic), and frailty have also been found to have a close relationship with the operative risk ${ }^{[9]}$. The ASA classification is widely used in anesthesia practice to evaluate the preoperative physical condition of patients with a wide range of diseases. Multimorbidity is common in patients aged 65 years and above ${ }^{[10]}$. There is also an increase in surgery among ASA III-IV group of patients, which isassociated with the increasing geriatric patient population with multiple morbidities. Indices such as $\mathrm{CCl}$ and $\mathrm{CACl}$ are used to determine comorbidity in surgical or internal problems ${ }^{[11]}$.

This retrospective study aimed to evaluate the relationship between postoperative survival and preoperative ASA and $\mathrm{mCCl}$ scores of geriatric patients who had undergone thoracic surgery.

\section{MATERIALS and METHODS}

We examined the hospital records of patients over 65 years who have undergone thoracic surgery under elective conditions in our hospital between January 2015 and May 2019 retrospectively. Patients in the geriatric age group who were operated under elective conditions in the thoracic surgery operating room were included in the study. The study was approved by the ethics committee of the hospital (decision number: 2018/514/144/1; Date: 26.12.2018). Patients who died within 24 hours postoperation, patients considered "in-operable" during the surgery or the surgery was terminated for any reason, and patients who developed surgical complications such as vascular injury, serious organ damage, or life threatening reactions due to anesthesia were excluded from the study. Patients with concomitant complications, emergency surgery patients, and pediatric patients were also excluded from the study.

One hundred and nine patients over 65 years who had undergone thoracic surgery were included in this study, which was designed as a retrospective study. Age, gender, weight, height, BMI, postoperati- 
F. D. Geyik ve ark., Association of American Society of Anesthesiology and Modified Charlson Comorbidty Index Scores with Survival in Geriatric Patients Undergoing Thoracic Surgery

ve survival, surgical method, comorbidity, ASA score, $\mathrm{mCCl}$ score, $\mathrm{mCCl}$ survival prediction percentage, operation time, double-lumen tube length and side, and the patients' position were recorded. Furthermore, the need for a central venous catheter, the amount of bleeding, the amount and type of fluid used, the need for blood transfusion, the length of stay in the intensive care unit, the length of hospital stay, complications, preoperative hemogram and biochemistry values, and postoperative hemogram and biochemistry values were recorded. After the study was approved by the ethics committee, the surgical records were checked by the assistant investigators. All patients who were 65 years or older and had undergone elective thoracic surgery were included in the study, while patients who were under 64 years andthose who had emergency surgery were excluded.

The collected data were analyzed with the Statistical Package for the Social Sciences $\left(\right.$ IBM $\left.^{\circledR}\right)$ version 23. The variables were characterized using mean, maximum and minimum values, and percentages. Normal distributions were reported as mean $\pm S D$, while Student's t-test was used for comparisons between groups. Pearson's chi-square test was used to analyze the quantitative variables; however, if the group was small, Fisher's exact test was used. Nonparametric continuous variables were recorded as median and spatial distribution and compared using MannWhitney $U$ tests. A value of $p<0.05$ was considered statistically significant.

The reliability of the calculated preoperative $\mathrm{mCCl}$ in predicting Exin2y was examined with the ROC curves, and the areas under the curve (AUCs) were evaluated. The patients were divided into two groups according to the threshold score value determined by $\mathrm{ROC}$ for $\mathrm{mCCl}$, and a comparison was made. For themultivariate analysis, only statistically significant variables (Ex in 2 year-Ex in 2 year) in the first two years in the univariate analysis were evaluated to determine the independent risk factors.

\section{RESULTS}

Preoperative, perioperative, and postoperative data of the patients included in the study are shown in Table 1,2. In the first two years postoperation, 18 of the patients died. Patients who died in the first two years had higher ASA III-IV scores $(p=0.03)$, higher $\mathrm{mCCl}$ scores $(p=0.04)$, lower hemoglobin and hematocrit values ( $p=0.02$ and $p=0.005$, respectively), and higher postoperative urea level than those who did not die $(p=0.03)$. Regarding the remaining variables, there was no statistically significant difference between the patients that died within the first two

Table 1. Preoperative demographic and clinical findings of the patients and their distrubition in terms of patients withhout mortality in the first $\mathbf{2}$ posterative years.

\begin{tabular}{|c|c|c|c|c|c|}
\hline $\begin{array}{l}\text { Variables } \\
\text { Preoperative }\end{array}$ & & $\begin{array}{c}\text { Total } \\
(n=107)\end{array}$ & $\begin{array}{c}\text { Exin2y (+) } \\
(n=18)\end{array}$ & $\begin{array}{c}\text { Exin2y }(-) \\
(n=89)\end{array}$ & $p$ value \\
\hline Age, year $\pm S D$ & Male & $70.4 \pm 4.7$ & $70.1 \pm 5.0$ & $70.4 \pm 4.7$ & 0.747 \\
\hline \multirow[t]{2}{*}{ Gender, n (\%) } & Female & $83(77.6 \%)$ & $12(66.7 \%)$ & $71(79.8 \%)$ & 0.224 \\
\hline & ASA I-II & $24(22.4 \%)$ & $6(33.3 \%)$ & $18(20.2 \%)$ & \\
\hline \multirow[t]{2}{*}{ ASA score, n (\%) } & ASA III-IV & $28(26.2 \%)$ & $1(5.6 \%)$ & 27 (30.3\%) & 0.037 \\
\hline & & $79(73.8 \%)$ & $17(94.4 \%)$ & $62(69.7 \%)$ & \\
\hline $\mathrm{mCCl}$ score, $\mathrm{n} \pm \mathrm{SD}$ & & $5.57 \pm 2.26$ & $6.55 \pm 2.14$ & $5.37 \pm 2.24$ & 0.045 \\
\hline \multirow[t]{2}{*}{ mCCI percentage, $\mathrm{n}(\%)$} & $0-21 \%$ & $69(64.5 \%)$ & $15(83.3 \%)$ & $54(60.7 \%)$ & 0.104 \\
\hline & $\geq 50$ & $3835.5 \%)$ & $3(16.7 \%)$ & 35 (39.3\%) & \\
\hline $\mathrm{BMI}, \mathrm{n} \pm \mathrm{SD}$ & & $25.8 \pm 1.5$ & & & 0.138 \\
\hline \multirow[t]{2}{*}{ Comorbidity, n (\%) } & Yes & 85 (79.4\%) & $15(83.3 \%)$ & $70(78.7 \%)$ & 0.654 \\
\hline & No & $22(20.6 \%)$ & $3(16.7 \%)$ & $19(21.3 \%)$ & \\
\hline Preop $\mathrm{Hg}, \mathrm{n} \pm \mathrm{SD}$ & & $12.5 \pm 1.4$ & $11.9 \pm 1.6$ & $12.7 \pm 1.3$ & 0.020 \\
\hline Preop Hct, $\mathrm{n} \pm \mathrm{SD}$ & & $37.6 \pm 4.2$ & $35.4 \pm 4.7$ & $38.0 \pm 3.9$ & 0.005 \\
\hline 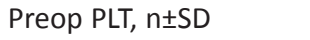 & & $262.1 \pm 104.9$ & $271.3 \pm 91.0$ & $260.2 \pm 107.8$ & 0.393 \\
\hline Preop WBC, $\mathrm{n} \pm \mathrm{SD}$ & & $8.4 \pm 3.6$ & $8.1 \pm 1.9$ & $8.5 \pm 3.8$ & 0.594 \\
\hline 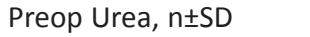 & & $38.6 \pm 13.2$ & $42.3 \pm 17.8$ & $37.8 \pm 12.0$ & 0.421 \\
\hline Preop Cre, $n \pm S D$ & & $0.88 \pm 0.29$ & $0.99 \pm 0.48$ & $0.86 \pm 0.23$ & 0.997 \\
\hline Preop ALT, n₫SD & & $20.3 \pm 11.9$ & $20.6 \pm 8.9$ & $20.3 \pm 12.5$ & 0.568 \\
\hline Preop AST, $n \pm S D$ & & $22.0 \pm 11.1$ & $19.7 \pm 9.2$ & $22.5 \pm 11.5$ & 0.211 \\
\hline
\end{tabular}


Table 2. Peroperative and postoperative demographic and clinical findings of the patients and their distrubition in terms of patients withhout mortality in the first 2 posterative years.

\begin{tabular}{|c|c|c|c|c|c|}
\hline $\begin{array}{l}\text { Variables } \\
\text { Intraoperative/postoperative }\end{array}$ & & $\begin{array}{c}\text { Total } \\
(n=107)\end{array}$ & $\begin{array}{c}\text { Exin2y }(+) \\
(n=18)\end{array}$ & $\begin{array}{c}\operatorname{Exin} 2 y(-) \\
(n=89)\end{array}$ & $p$ value \\
\hline \multirow[t]{2}{*}{ Operation type, n (\%) } & Open & $66(61.7 \%)$ & $8(44.4 \%)$ & $58(65.2 \%)$ & 0.099 \\
\hline & Closed & $41(38.3 \%)$ & $10(55.6 \%)$ & $31(34.8 \%)$ & \\
\hline \multirow[t]{3}{*}{ Operation mode, n (\%) } & Anatomic resec. & $65(60.7 \%)$ & $9(50.0 \%)$ & $56(62.9 \%)$ & 0.259 \\
\hline & Nonanatomic resec & $26(24.3 \%)$ & $5(27.8 \%)$ & $21(23.6 \%)$ & \\
\hline & Other & $16(15.0 \%)$ & $4(22.2 \%)$ & $12(13.5 \%)$ & \\
\hline Operation time, $\min \pm S D$ & & $167.6 \pm 42.8$ & $158.0 \pm 40.4$ & $169.6 \pm 43.3$ & 0.249 \\
\hline Amount of bleeding, $\mathrm{ml} \pm \mathrm{SD}$ & & $449.0 \pm 401.3$ & $569.4 \pm 692.8$ & & 0.906 \\
\hline Crystalloid, $\mathrm{ml} \pm \mathrm{SD}$ & & $2273.8 \pm 565.2$ & $2194.4 \pm 667.2$ & $2289.8 \pm 545.2$ & 0.674 \\
\hline Colloid, $\mathrm{ml} \pm \mathrm{SD}$ & & $488.8 \pm 125.0$ & $500.0 \pm 0.0$ & $478.5 \pm 132.9$ & 0.689 \\
\hline \multirow[t]{2}{*}{ Blood transfusion, $\mathrm{n}(\%)$} & Yes & $29(26.2 \%)$ & $6(33.3 \%)$ & $23(25.8 \%)$ & 0.514 \\
\hline & No & $79(73.8 \%)$ & $12(66.7 \%)$ & $66(74.2 \%)$ & \\
\hline \multirow[t]{2}{*}{ Complication, n (\%) } & Yes & $24(22.4 \%)$ & $4(22.2 \%)$ & $20(22.5 \%)$ & 0.982 \\
\hline & No & $83(77.6 \%)$ & $14(77.8 \%)$ & $69(77.5 \%)$ & \\
\hline Postop Hg, $\mathrm{n} \pm \mathrm{SD}$ & & $11.5 \pm 1.4$ & $11.2 \pm 1.3$ & $11.5 \pm 1.4$ & 0.233 \\
\hline Postop Hct, $n \pm S D$ & & $34.5 \pm 4.2$ & $33.8 \pm 3.8$ & $34.6 \pm 4.3$ & 0.332 \\
\hline Postop PLT, $n \pm S D$ & & $280.2 \pm 130.3$ & $263.6 \pm 111.0$ & $283.5 \pm 134.2$ & 0.635 \\
\hline Postop WBC, $n \pm S D$ & & $11.2 \pm 4.2$ & $12.2 \pm 5.5$ & $11.0 \pm 4.0$ & 0.745 \\
\hline Postop Urea, $n \pm S D$ & & $41.2 \pm 18.4$ & $47.6 \pm 18.2$ & $39.9 \pm 18.3$ & 0.034 \\
\hline Postop Creatinine, $n \pm S D$ & & $0.89 \pm 0.34$ & $1.01 \pm 0.52$ & $0.86 \pm 0.29$ & 0.787 \\
\hline Postop ALT, $\mathrm{n} \pm \mathrm{SD}$ & & $27.5 \pm 25.2$ & $29.5 \pm 34.2$ & $27.1 \pm 23.2$ & 0.346 \\
\hline Postop AST, $\mathrm{n} \pm \mathrm{SD}$ & & $34.8 \pm 27.1$ & $34.8 \pm 28.5$ & $34.8 \pm 27.0$ & 0.602 \\
\hline ICU admission, n (\%) & & $79(73.8 \%)$ & $15(83.3 \%)$ & $64(71.9 \%)$ & 0.315 \\
\hline ICU stay, day \pm SD & & $2.7 \pm 2.2$ & $3.6 \pm 3.2$ & $2.5 \pm 1.9$ & 0.325 \\
\hline LOS, day $\pm S D$ & & $8.3 \pm 4.4$ & $8.0 \pm 3.4$ & $8.4 \pm 4.6$ & 0.997 \\
\hline
\end{tabular}

years postoperation and those who did not.

When we compared the relationship between $\mathrm{mCCl}$ and death in the first two years postoperation, together with ROC analysis, we found that $\mathrm{mCCl}$ was sig-

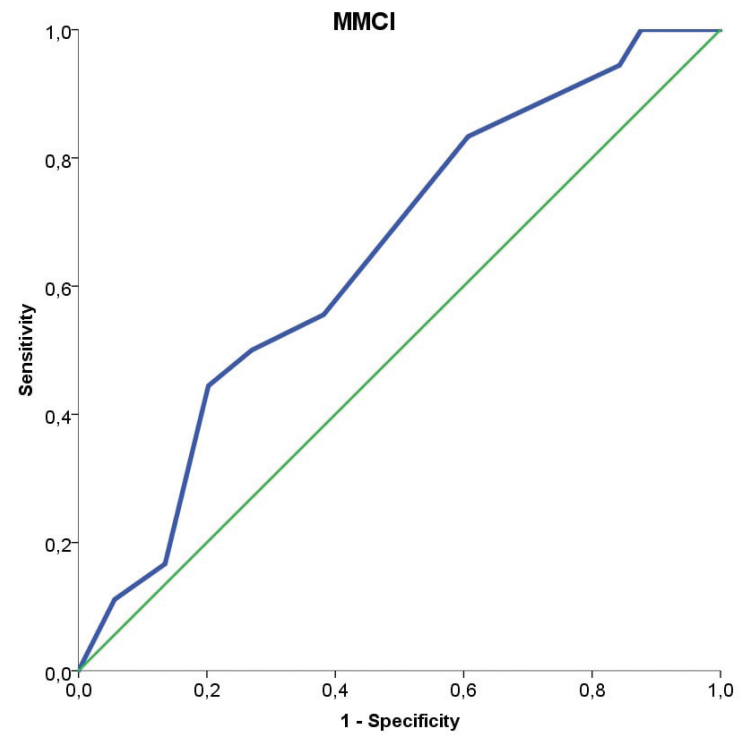

Figure 1. ROC analysis of $\mathrm{mCCl}$ in mortality. nificantly effective in predicting two-year mortality among the geriatric patients $(A \cup C=0.648,95 \% \mathrm{Cl}$ : $0.516-0.780, p=0.02$; Figure 1 ). In the ROC analysis, the best predictive cutoff value for $\mathrm{mCCl}$ was found to be 7 (sensitivity: $79.7 \%$, specificity: $44.4 \%$ ). Using this cutoff value for $\mathrm{mCCl}$, the patients were divided into two groups: the high $\mathrm{mCCl}$ group (>7, $\mathrm{n}=26$ ) and low $\mathrm{mCCl}$ group ( $\leq 7, \mathrm{n}=81)$. Patients with high $\mathrm{mCCl}$ had higher mortality in the first two years than those with low $\mathrm{mCCl}(69.2 \%$ vs. $12.3 \%$, $p=0.02$ ). The analysis revealed that those with high ASA scores $(p<0.0001)$ and those with comorbidities $(p=0.01)$ were more in the high $\mathrm{mCCl}$ group, and this was found to be statistically significant (Table 3 , 4). There was no significant difference between the high $\mathrm{mCCl}$ and low $\mathrm{mCCl}$ groups in terms of other variables.

The multivariate analysis was performed using patients with high $\mathrm{mCCl}$ scores $(>7)$ that were found to significantly affect mortality to determine the independent variables that affected mortality in the first two years (Table 1, 2). An $\mathrm{mCCl}$ score above 7 $(p=0.02)$ was the only independent variable that 
F. D. Geyik ve ark., Association of American Society of Anesthesiology and Modified Charlson Comorbidty Index Scores with Survival in Geriatric Patients Undergoing Thoracic Surgery

Table 3. Categorization of patients according to $\mathrm{mCCl}$ cutoff value determined by ROC and comparison between these groups in Preoperative period.

\begin{tabular}{|c|c|c|c|c|}
\hline $\begin{array}{l}\text { Variables } \\
\text { Preoperative }\end{array}$ & & $\begin{array}{c}m C C l \leq 7 \\
(n=81)\end{array}$ & $\begin{array}{c}\mathrm{mCCl}>7 \\
(n=26)\end{array}$ & $p$ value \\
\hline Age, year $\pm S D$ & & $70.1 \pm 4.3$ & $71.0 \pm 6.0$ & 1.000 \\
\hline \multirow{2}{*}{ Gender, n (\%) } & Male & $66(81.5 \%)$ & $17(65.4 \%)$ & 0.087 \\
\hline & Female & 15 (18.5\%) & $9(34.6 \%)$ & \\
\hline \multirow[t]{2}{*}{ ASA score, n (\%) } & ASA I-II & $28(34.6 \%)$ & $0(0 \%)$ & $<0.0001$ \\
\hline & ASA III-IV & $53(65.4 \%)$ & $26(100.0 \%)$ & \\
\hline $\mathrm{BMI}, \mathrm{n} \pm \mathrm{SD}$ & & $25.9 \pm 1.5$ & $25.4 \pm 1.3$ & 0.155 \\
\hline \multirow[t]{2}{*}{ Comorbidity, n (\%) } & Yes & $60(74.1 \%)$ & $25(96.2 \%)$ & 0.013 \\
\hline & No & $21(25.9 \%)$ & $1(3.8 \%)$ & \\
\hline Preop Hg, $\mathrm{n} \pm \mathrm{SD}$ & & $12.5 \pm 1.3$ & $12.7 \pm 1.6$ & 0.601 \\
\hline Preop Hct, $n \pm S D$ & & $37.5 \pm 4.0$ & $37.8 \pm 4.7$ & 0.813 \\
\hline Preop PLT, n₫SD & & $270.5 \pm 112.1$ & $235.8 \pm 74.2$ & 0.151 \\
\hline Preop WBC, $n \pm S D$ & & $8.6 \pm 3.6$ & $7.7 \pm 3.3$ & 0.092 \\
\hline Preop Urea, $n \pm S D$ & & $38.6 \pm 13.6$ & $38.5 \pm 12.0$ & 0.591 \\
\hline Preop Creatinine, $n \pm S D$ & & $0.89 \pm 0.27$ & $0.85 \pm 0.34$ & 0.225 \\
\hline Preop ALT, $n \pm S D$ & & $19.6 \pm 8.7$ & $22.6 \pm 18.8$ & 0.655 \\
\hline Preop AST, $n \pm S D$ & & $20.9 \pm 7.8$ & $25.6 \pm 17.7$ & 0.332 \\
\hline
\end{tabular}

Table 4. Categorization of patients according to $\mathrm{mCCl}$ cutoff value determined by ROC and comparison between these groups in Intraoperative/postoperative period.

\begin{tabular}{|c|c|c|c|c|}
\hline $\begin{array}{l}\text { Variables } \\
\text { Intraoperative/postoperative }\end{array}$ & & $\begin{array}{c}\mathrm{mCCl} \leq 7 \\
(\mathrm{n}=81)\end{array}$ & $\begin{array}{c}\mathrm{mCCl}>7 \\
(n=26)\end{array}$ & $p$ value \\
\hline \multirow[t]{2}{*}{ Operation type, n (\%) } & Open & $49(60.5 \%)$ & $17(65.4 \%)$ & 0.655 \\
\hline & Closed & $32(39.5 \%)$ & $9(34.6 \%)$ & \\
\hline \multirow[t]{3}{*}{ Operation mode, n (\%) } & Anatomic resec. & $50(61.7 \%)$ & $15(57.7 \%)$ & 0.926 \\
\hline & Nonanatomic resec & $19(23.5 \%)$ & $7(26.9 \%)$ & \\
\hline & Other & $12(14.8 \%)$ & $4(15.4 \%)$ & \\
\hline Operation time, $\min \pm S D$ & & $165.6 \pm 43.4$ & $173.8 \pm 41.3$ & 0.404 \\
\hline Amount of bleeding, $\mathrm{ml} \pm \mathrm{SD}$ & & $433.3 \pm 339.2$ & $498.0 \pm 558.1$ & 0.881 \\
\hline Crystalloid, $\mathrm{ml} \pm \mathrm{SD}$ & & $2225.9 \pm 594.3$ & $2423.0 \pm 440.8$ & 0.089 \\
\hline 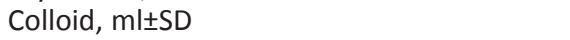 & & $463.6 \pm 78.9$ & $600.0 \pm 223.6$ & 0.208 \\
\hline \multirow[t]{2}{*}{ Blood transfusion, $\mathrm{n}(\%)$} & Yes & $22(27.2 \%)$ & 7 (26.9\%) & 0.981 \\
\hline & No & $59(72.8 \%)$ & $19(73.1 \%)$ & \\
\hline \multirow[t]{2}{*}{ Complication, n (\%) } & Yes & $21(25.9 \%)$ & $3(11.5 \%)$ & 0.126 \\
\hline & No & $60(74.1 \%)$ & $23(88.5 \%)$ & \\
\hline Postop $\mathrm{Hg}, \mathrm{n} \pm \mathrm{SD}$ & & $11.4 \pm 1.4$ & $11.7 \pm 1.6$ & 0.450 \\
\hline Postop Hct, $\mathrm{n} \pm \mathrm{SD}$ & & $34.3 \pm 4.3$ & $35.2 \pm 4.2$ & 0.463 \\
\hline Postop PLT, $\mathrm{n} \pm \mathrm{SD}$ & & $289.4 \pm 122.7$ & $251.4 \pm 150.7$ & 0.033 \\
\hline Postop WBC, $\mathrm{n} \pm \mathrm{SD}$ & & $11.1 \pm 4.1$ & $11.3 \pm 4.8$ & 0.856 \\
\hline Postop Urea, $\mathrm{n} \pm \mathrm{SD}$ & & $41.9 \pm 0.0$ & $39.1 \pm 12.3$ & 1.000 \\
\hline Postop Creatinine, $\mathrm{n} \pm \mathrm{SD}$ & & $0.90 \pm 0.35$ & $0.86 \pm 0.33$ & 0.492 \\
\hline Postop ALT, $\mathrm{n} \pm \mathrm{SD}$ & & $25.7 \pm 21.7$ & $33.1 \pm 34.0$ & 0.588 \\
\hline Postop AST, $\mathrm{n} \pm \mathrm{SD}$ & & $33.5 \pm 25.7$ & $38.9 \pm 31.4$ & 0.705 \\
\hline ICU admission, $\mathrm{n}(\%)$ & & $58(71.6 \%)$ & $21(80.8 \%)$ & 0.355 \\
\hline ICU stay, day \pm SD & & $2.7 \pm 2.3$ & $2.6 \pm 2.0$ & 0.797 \\
\hline LOS, day \pm SD & & $8.3 \pm 4.0$ & $8.3 \pm 5.5$ & 0.622 \\
\hline Deaths witihin Postoperative 2 years, n (\%) & & $10(12.3 \%)$ & $18(69.2 \%)$ & 0.029 \\
\hline
\end{tabular}

affected mortality and was thus found to be a risk factor (Table 5). The fact that ASA was III-IV showed a near-significant trend toward affecting mortality $(p=0.07)$.

\section{DISCUSSION}

This study attempted to identify two different scoring systems and other factors affecting survival in 
Tablo 5. Multivariate Logistic Regression Analysis for Postoperative Mortality in two years*.

Multivariate analysis-1

\begin{tabular}{|c|c|c|c|c|c|c|}
\hline \multirow[b]{2}{*}{ Variables } & & \\
\hline & Odds ratio & $95 \% \mathrm{Cl}$ & $p$ value & Odds ratio & $95 \% \mathrm{Cl}$ & $p$ value \\
\hline PreopHg & 1.662 & $0.518-5.392$ & 0.392 & 1.662 & $0.518-5.392$ & 0.392 \\
\hline PreopHtc & 0.745 & $0.496-1.119$ & 0.157 & 0.745 & $0.496-1.119$ & 0.157 \\
\hline PostopUrea & 1.014 & 0.988-1.041 & 0.290 & 1.014 & $0.988-1.041$ & 0.290 \\
\hline ASA III-IV & 6.547 & $0.808-53.037$ & 0.07 & 6.547 & $0.808-53.037$ & 0.07 \\
\hline $\mathrm{mCCl}>7$ & -- & -- & -- & -- & -- & -- \\
\hline
\end{tabular}

* For multivariate analysis, $\mathrm{mCCl}>7$ was used with the independent variables determined to affect the development of mortality in Table 1. In Multivariate analysis-1, independent variables affecting mortality and ASA were analyzed together, while in Multivariate analysis-2, $\mathrm{mCCl}$ was used with independent variables affecting mortality.

geriatric patients who had undergone thoracic surgery. High ASA and $\mathrm{mCCl}$ scores, low hemogram values, and high postoperative renal function markers were determined as poor prognostic factors. There was no significant difference in prognosis with other variables. ASA scoring system is a risk classification based on the presence and severity of comorbidities and is used to determine the perioperative risk of a procedure ${ }^{[12]}$. Various studies have stated that the ASA score may affect mortality in geriatric patients. Mortality has been found to be higher in geriatric patients with high ASA scores such as ASA III-IV [13]. This is consistent with our study, as ASA score was found to be higher in patients who died. According to Cook and Rooke, limited physiological reserve in geriatric patients may cause an increased risk of complications and mortality after surgical operation ${ }^{[14]}$. Geriatric patients represent a significant portion of the population undergoing surgery, and this patient population is increasing. Since geriatric patients have a high prevalence of comorbidity and perioperative complication rate, careful preoperative evaluation should be performed ${ }^{[15]}$. In European countries, mortality from lung cancer is more common in women than mortality from breast cancer ${ }^{[16]}$. The average age of patients who applied to clinics for lung cancer was found to be 71 years, and lung cancer is the leading cause of cancerrelated death in elderly patients ${ }^{[17]}$.

$\mathrm{CCl}$ is the most widely used method for predicting comorbidity and mortality in patients ${ }^{[18]}$. It was developed to determine the risk of mortality and has been used by different clinics ${ }^{[19]}$. Infante et al. ${ }^{[20]}$, in their retrospective study among 163 patients who underwent thoracic surgery, stated that age-added
$\mathrm{CCl}$ score was the only independent prognostic factor in determining mortality. Nakada et al. ${ }^{[21]}$ found a significant relationship between the postoperative complication rate and high $\mathrm{CCl}$ score in patients who underwent thoracoscopic lobectomy. In our study, a high $\mathrm{mCCl}$ score was also significant as a poor prognostic criterion for demonstrating mortality. Also, when the relationship between $\mathrm{mCCl}$ and death in the first two years postoperation was analyzed together with ROC analysis, we found that $\mathrm{mCCl}$ was significantly effective in predicting two-year mortality (AUC=0.648, 95\% Cl: 0.516-0.780, $p=0.02)$. In the ROC analysis, the best predictive cutoff value for $\mathrm{mCCl}$ was found to be 7 (sensitivity: $79.7 \%$, specificity: $44.4 \%)$.

When patients were divided into two groups using the $\mathrm{mCCl}$ cutoff value-the high $\mathrm{mCCl}$ group and the low $\mathrm{mCCl}$ group-patients with high $\mathrm{mCCl}$ had more mortality in the first two years than those with low $\mathrm{mCCl}(69.2 \%$ vs $12.3 \%, \mathrm{p}=0.02)$. Those with high ASA scores $(p<0.0001)$ and those with comorbidity $(p=0.01)$ were found to be more in the high $\mathrm{mCCl}$ group, and this was statistically significant.

Multivariate analysis was performed using patients with high $\mathrm{mCCl}(>7)$ foundto significantly affect mortality todetermine the independent variables that affect the mortality rate in the first two years, $\mathrm{mCCl}$ score above seven ( $p=0.02)$ was found to be the only independent risk factor affecting mortality (Table 5). The fact that ASA is III-IV showed a near-significant trend toward affecting mortality $(p=0.07)$. These findings also support our above conclusion.

Several other factors may have effects on mortality 
F. D. Geyik ve ark., Association of American Society of Anesthesiology and Modified Charlson Comorbidty Index Scores with Survival in Geriatric Patients Undergoing Thoracic Surgery

among elder patients who had undergone thoracic surgery ${ }^{[22]}$. Eguchi et al. ${ }^{[23]}$ conducted a retrospective study of early-stage NSCLC (non-small cell lung cancer) patients who underwent lung resection to equate cancer-related mortality to non-cancer-related mortality in the context of increasing age. Tanner et al. ${ }^{[24]}$ used the SEER and NLST datasets to look at the results of elderly patients with minor morbidities who took part in a screening experiment. According to this report, patients with severe comorbidities can see a lower gain from screening. Haruki et al. ${ }^{[25]}$ used a Simplified Comorbidity Score to estimate postoperative morbidity and prognosis in a retrospective analysis. Patients with higher Simplified Comorbidity Scores have more postoperative problems, according to the researchers. Jung et al. ${ }^{[26]}$ observed that acute respiratory distress syndrome and delirium were independent risk factors for in-hospital mortality in a systematic study of patients admitted to the ICU following initial discharge from major lung surgery.

\section{CONCLUSION}

High ASA and mCCl scores, low hemogram values, and high postoperative renal function markers were determined as poor prognostic factors. In our study, preoperative hemoglobin and hematocrit values were found to be lower in patients who died and were statistically significant. This result can be evaluated as a new factor affecting mortality. Thoracic anesthesiologists must consider the high perioperative danger, which is dependent on age-related physiological changes and the presence of comorbidities.

\section{REFERENCES}

1. Jacob R. Anesthesia for thoracic surgery in children in developing countries. Paediatr Anaesth 2009;19:1922. (PMID 19076497) https://doi.org/10.1111/j.1460-9592.2008.02865.x

2. Haynes SR, Bonner S. Review article: anesthesia for thoracic surgery in children. Paediatr Anaesth 2000;10:237-51. (PMID: 10792739) https://doi.org/10.1046/j.1460-9592.2000.00444.x

3. Charlson ME, Pompei P, Ales KL, et al. A new method of classifying prognostic comorbidity in longitudinal studies: development and validation. J Chronic Dis 1987;40:373-83. (PMID: 3558716) https://doi.org/10.1016/0021-9681(87)90171-8

4. Bernasconi F, Piccioni F. One-lung ventilation for thora- cic surgery: current perspectives. Tumori. 2017;103(6):495-503. (PMID: 28604996) https://doi.org/10.5301/tj.5000638

5. Morgan GE, Mikhail MS, Murray MJ, et al. Anesthesia for thoracic surgery. In: Morgan GE, Mikhail MS, Murray MJ, Larson CP (eds). Clinical anesthesiology. $3 r d$ ed. New York: McGraw-Hill Companies 2002;52551.

6. Weiser TG, Regenbogen SE, Thompson KD, et al. An estimation of the global volume of surgery: a modeling strategy based on available data. Lancet. 2008;372(9633):139-44. (PMID: 18582931) https://doi.org/10.1016/S0140-6736(08)60878-8

7. Murray D, Dodds C. Pre-operative assessment of the elderly. BJA CEPD Reviews 2001;1(6):181-4. https://doi.org/10.1093/bjacepd/1.6.181

8. White A, Kucukak S, Bueno R, et al. Pneumonectomy is safe and effective for non-small cell lung cancer following induction therapy. J Thorac Dis 2017;9(11):444753. (PMID: 29268514) https://doi.org/10.21037/jtd.2017.10.92

9. Fontana L, Kennedy Brian K, Longo Valter D et al. Medical research: treat aging. Nature 2014;511(7510):405-7. (PMID: 25056047) https://doi.org/10.1038/511405a

10. Guerra SG, Berbiche D, Vasiliadis HM. Measuring multimorbidity in older adults: comparing different data sources. BMC Geriatr. 2019 Jun 14;19(1):166. (PMID: 31200651) https://doi.org/10.1186/s12877-019-1173-4

11. Moltó A, Dougados M. Comorbidity indices. Clin Exp Rheumatol. 2014;32(5 Suppl 85):S-131-4. (PMID: 25365102)

12. Sarfati D, Koczwara B, Jackson C. The impact of comorbidity on cancer and its treatment. CA Cancer J Clin 2016;66:337-50. (PMID: 26891458) https://doi.org/10.3322/caac.21342

13. Haroon N, Mh A, Chafiki Z. Age-adjusted Charlson comorbidity Index: predictor of 90-day mortality after radical cystectomy. J Surg Oper Care 2016;1:1-6. https://doi.org/10.15744/2455-7617.1.204

14. Jiang J, Lan Y, Lin T, et al. Primary vs. delayed resection for obstructive left-sided colorectal cancer: impact of surgery on patient outcome. Dis. Colon \& Rectum 2008;51:306-11. (PMID: 18183462) https://doi.org/10.1007/s10350-007-9173-4

15. Cook DJ, Rooke GA. Priorities in perioperative geriatrics. Anesth Analg. 2003;96(6):1823-36. (PMID: 12761020) https://doi.org/10.1213/01.ANE.0000063822.02757.41

16. Warren B Chow, Ronnie A Rosenthal, Ryan P Merkow, et al. Optimal preoperative assessment of the geriatric surgical patient: a best practice guideline from the American College of Surgeons National Surgical Quality Improvement Program and the American Geriatrics Society. J Am Coll Surg. 2012;215(4):453-66. (PMID: 22917646) https://doi.org/10.1016/j.jamcollsurg.2012.06.017

17. Ferlay J, Steliarova-Foucher E, Lortet-Tieulent J, et al. Cancer incidence and mortality patterns in Europe: estimates for 40 countries in 2012. Eur J Cancer 2013;49:1374-403. (PMID: 23485231) https://doi.org/10.1016/j.ejca.2012.12.027

18. Jemal A, Siegel R, Ward E, et al. Cancer statistics, 2006. 
CA Cancer J Clin 2006;56:106-30. (PMID: 16514137) https://doi.org/10.3322/canjclin.56.2.106

19. Barnett S, Moonesinghe SR. Clinical risk scores to guide perioperative management. Postgrad Med J. 2011;87(1030):535-41. (PMID: 21257993)

https://doi.org/10.1136/pgmj.2010.107169

20. Infante M, Morenghi E, Bottoni E, et al. Comorbidity, postoperative morbidity, and survival in patients undergoing radical surgery for malignant pleural mesothelioma. Eur J Cardiothorac Surg 2016;50:107782. (PMID: 27330149) https://doi.org/10.1093/ejcts/ezw215

21. Nakada T, Noda Y, Kato D, et al. Risk factors and cancer recurrence associated with postoperative complications after thoracoscopic lobectomy for clinical stage I non-small cell lung cancer. Thorac Cancer 2019;10:194552. (PMID: 31436042) https://doi.org/10.1111/1759-7714.13173

22. Castillo M. An overview of perioperative considerations in elderly patients for thoracic surgery: demographics, risk/benefit, and resource planning. Curr Opin Anaesthesiol. 2018 Feb;31(1):1-5. PMID: 29120933.
https://doi.org/10.1097/ACO.0000000000000535

23. Eguchi $T$, Bains $S$, Lee $M$, et al. Impact of increasing age on cause-specific mortality and morbidity in patients with stage I nonsmall-cell lung cancer: a competing risks analysis. J Clin Oncol 2017;35:281-90. (PMID: 28095268) https://doi.org/10.1200/JCO.2016.69.0834

24. Tanner NT, Dai L, Bade BC, et al. Assessing the generalizability of the National Lung Screening Trial: comparison of patients with stage I disease. Am J Respir Crit Care Med 2017; 196:602-8. (PMID: 28722466) https://doi.org/10.1164/rccm.201705-09140C

25. Haruki T, Yurugi $Y$, Wakahara $M$, et al. Simplified comorbidity score for elderly patients undergoing thoracoscopic surgery for lung cancer. Surg Today 2017;47:718-25. (PMID: 27699490) https://doi.org/10.1007/s00595-016-1427-0

26. Jung JJ, Cho JH, Hong TH, et al. Intensive care unit (ICU) readmission after major lung resection: prevalence, patterns, and mortality. Thorac Cancer 2017;8:33-9. (PMID:27925393) https://doi.org/10.1111/1759-7714.12406 